\title{
Co-elimination of mec and spa genes in Staphylococcus aureus and the effect of agr and protein A production on bacterial adherence to cell monolayers
}

\author{
S. M. POSTON, G. R. GLANCEY*, J. E. WYATT, T. HOGAN $\dagger$ and T. J. FOSTER $\dagger$ \\ Department of Microbiology, UMDS, Guy's Medical School, * Renal Unit, UMDS, Guy's Hospital, London Bridge \\ SE1 9RT and †Department of Microbiology, Moyne Institute, Trinity College, Dublin 2
}

\begin{abstract}
Summary. Phenotypic loss of protein A production was tested in six methicillin-resistant $\left(\mathrm{Mc}^{\mathrm{R}}\right)$ Staphylococcus aureus (MRSA) isolates and their isogenic methicillin-sensitive (Mc $\left.\mathrm{Mc}^{\mathrm{S}}\right)$ variants by a radiolabelled IgG-binding assay with washed cells and by Western blotting of supernates prepared from lysed washed cells. Genomic DNA was probed for homology with the protein A gene ( $s p a$ ) in EcoRI digests and for homology to the methicillin resistance gene $(\mathrm{mec})$ in HindIII digests. The $\mathrm{Mc}^{\mathrm{s}}$ variants had lost homology with mec. An isogenic pair of $\mathrm{Mc}^{\mathrm{R}}$ and $\mathrm{Mc}^{\mathrm{s}}$ strains, and derivatives of $S$. aureus $8325-4$ with site-specific mutations of the accessory gene regulator locus (agr) and spa, were tested for adherence to human peritoneal mesothelial cells in monolayer culture. The isogenic pair were also tested for adherence to HEp-2 and Vero cell monolayers in assays with ${ }^{3} \mathrm{H}$ thymidine-labelled bacteria. $\mathrm{Mc}^{\mathrm{R}}$ isolates produced protein $\mathrm{A}$ which was absent from three strains that had become $\mathrm{Mc}^{\mathrm{s}}$. This correlated with deletion of the spa locus. Spa homology, but reduced production of protein $\mathrm{A}$, was retained in one $\mathrm{Mc}^{\mathrm{s}}$ strain which also showed reduced adherence to HEp-2, Vero and mesothelial cells $(\mathrm{p}<0.05)$ compared with the parent $\mathrm{Mc}^{\mathrm{R}}$ strain. A spa mutation in strain 8325-4 did not significantly affect adherence to mesothelial cells but mutation in agr increased adherence significantly in both $\mathrm{Spa}^{+}$and $\mathrm{Spa}^{-}$strains.
\end{abstract}

\section{Introduction}

Staphylococcus aureus is able to colonise several superficial sites in the body, particularly the nasal mucosa and perineum. ${ }^{1,2}$ Carriers of $S$. aureus have an increased risk of infection of surgical wounds and peritoneal dialysis catheter exit sites. ${ }^{3-6}$ It is assumed that bacterial adherence to tissues is required for colonisation to occur. ${ }^{7}$ Adherence studies have used monolayers of continuous cell lines ${ }^{7,8}$ and primary cultures of mesothelial cells which line the peritoneal cavity. ${ }^{9-11}$ Although the adherence mechanisms of $S$. aureus are not clearly defined, the inclusion of cell-wall fractions of lipoteichoic or teichoic acid and of protein $A$ in adherence assays have been shown to reduce adherence. $^{10}$

$S$. aureus also has fibronectin-binding protein(s) and it is presumed that these are involved in adherence. ${ }^{12-14}$ Fibronectin is produced by mesothelial and epithelial cells but is not detected on the surface of transformed cells such as HEp-2 or Vero cell monolayers. ${ }^{15-17}$ Cellular fibronectin is located in the basement membrane of epithelial cells ${ }^{17}$ which may be exposed following trauma. S. aureus also binds to fibrinogen. ${ }^{18,19}$

Received 24 Sept. 1992; revised version accepted 18 May 1993.
In $S$. aureus, expression of cell-bound and extracellular proteins is controlled by the accessory gene regulator (agr) locus. ${ }^{20,21}$ In assays with a strain deleted for $\operatorname{agr}\left(a g r^{-}\right)$, S. aureus proteins have been categorised into four classes (I-IV), based on the amount of protein produced during different phases of growth. ${ }^{22}$ In $a g r^{+}$bacteria, protein $\mathrm{A}$ and fibronectin-binding proteins (Class III) are produced maximally during exponential growth whereas the extracellular protein, toxic shock syndrome toxin (TSST-1, Class I), is produced maximally in the post-exponential phase. ${ }^{22}$ In agr $^{-}$mutants in the post-exponential phase, Class III proteins are produced at high levels and Class I proteins are undetectable. The regulation of exoprotein synthesis by the agr locus has characteristics of two-component systems. These involve signal transduction proteins which enable the organism to respond rapidly to environmental change. In $S$. aureus, the AgrB protein provides sensor function and AgrA is involved in the regulation of gene expression, acting as a transcriptional activator. ${ }^{22}$ As a result, exoprotein gene expression is increased and cell-bound protein is decreased in post-exponential growth.

Methicillin-resistant $\left(\mathrm{Mc}^{\mathrm{R}}\right)$ S. aureus (MRSA) may exhibit spontaneous deletion of the methicillin resistance gene $(m e c){ }^{23}$ In epidemic Australian and London (EMRSA-1) strains, this is accompanied by 
loss of resistance to mercury and cadmium and reduced resistance to tetracycline. ${ }^{24-26}$ Production of protein A also can be co-eliminated with resistance to methicillin and re-introduced by transduction or transformation. ${ }^{27}$ Introduction of methicillin resistance can also modify levels of protein $\mathrm{A}$ expression. ${ }^{27}$ The protein A gene (spa) maps near mec on the chromosome of strain $8325 .^{28}$

In this study, the production of protein $A$ and homology for spa in MRSA and isogenic methicillinsensitive $\left(\mathrm{Mc}^{\mathrm{s}}\right)$ variants was examined and the adherence of one pair of strains to cell monolayers was compared. Mutant strains for the spa and agr genes of $S$. aureus 8325-4 were compared for adherence to mesothelial cells.

\section{Materials and methods}

\section{Bacterial strains}

$S$. aureus strains used in this study are listed in table I. Six isolates of MRSA and $\mathrm{Mc}^{\mathrm{s}}$ variants derived from them have been described previously. ${ }^{26}$ Isolates $\mathrm{GH} 13$, GH25, GH28 and GH31 are EMRSA-1. ${ }^{30} \mathrm{Mc}^{\mathrm{s}}$ variants are designated by the parent strain number with the suffix -01 . Strain $8325-4$ is a non-lysogenic variant of strain NCTC $8325 .{ }^{31}$ Mutants of strain 8325-4 were derived by allele replacement of the spa locus by insertion of an ethidium bromide resistance determinant $\left(\Delta s p a:: \mathrm{Eb}^{\mathrm{r}}\right)$ and by $\mathrm{Tn} 551$ insertion in the agr locus as described previously. ${ }^{32,33}$ Strain DU5818 was constructed by transducing agr::Tn551 into strain DU5723 (8325-4 $\Delta$ spa:: $\left.\mathrm{Eb}^{\mathrm{r}}\right)$ with bacteriophage 85 and selecting for erythromycin resistance. $S$. aureus strains Wood 46 (ISP740) and Cowan I (ISP393) was provided by Dr P. A. Pattee (Department of Microbiology, Iowa State University, Iowa 50011, USA).

\section{Media}

Tryptic Soy Broth (TSB; Oxoid) solidified with agar (Oxoid no. 1) 1\% w/v was used for routine culture. Bacteria were grown in IsoSensitest broth (IST; Oxoid) for adherence assays and in TSB for protein A determinations.

\section{Detection of protein $A$}

Cell-bound protein A was detected in washed cells by a liquid phase radiolabelled IgG-binding assay based on the method of Uhlen et al. ${ }^{34}$ Strains were grown overnight in TSB, centrifuged and washed twice in phosphate-buffered saline with Tween $200.5 \% \mathrm{v} / \mathrm{v}$ (PBST). Bacteria were resuspended in PBST to $\mathrm{OD}_{540}$ 0.4 , equivalent to a total count of $c .5 \times 10^{8}$ organisms/ $\mathrm{ml}$ in a Helber counting chamber. Six replicate 1-ml samples were pelleted and resuspended in $200 \mu \mathrm{l}$ of ${ }^{125} \mathrm{I}$-labelled rabbit $\operatorname{IgG}(1 \mathrm{mg} / \mathrm{L})$. After incubation for $1 \mathrm{~h}$ with shaking at $37^{\circ} \mathrm{C}$, the cells were washed twice with PBST and bound radioactivity was counted in a gamma counter. Duplicate assays were performed for each strain. Results were calculated as the amount of radiolabelled IgG bound as a percentage of the initial cpm used. The concentration of IgG used in this study was not tested for saturation of protein $\mathrm{A}$ and, therefore, in positive strains, higher levels of protein than those detected in the assay may have been present. $S$. aureus Cowan I was included as a known positive strain and Wood 46 as a negative or very low-level producer of protein $\mathrm{A}^{34}$

Western immunoblotting was used to detect protein A in supernates prepared from lysed washed cells. Cells $(1.5 \mathrm{ml})$ grown to saturation in TSB were centrifuged for $30 \mathrm{~s}$, resuspended and washed in $450 \mu \mathrm{l}$ of TE buffer (10 mM Tris-HCl, $1 \mathrm{~mm}$ EDTA, pH 8.0). DNAase 1 (Sigma) $10 \mu \mathrm{g}$ and pancreatic RNAase (Sigma) $10 \mu \mathrm{g}$ were added along with $50 \mu \mathrm{g}$ of recombinant lysostaphin (Applied Microbiology Inc., New York) and the mixture was incubated at $37^{\circ} \mathrm{C}$ for $30 \mathrm{~min}$. The lysate was centrifuged at $11000 \mathrm{~g}$ for $15 \mathrm{~min}$. The protein concentration of the supernate was measured by the method of Lowry et al.$^{35}$ Between 2 and $10 \mu \mathrm{l}$ was boiled with final sample buffer (volume made up to $20 \mu \mathrm{l}$ ) and applied to a discontinuous SDSpolyacrylamide $12.5 \%$ gel. $^{36}$

Proteins separated by SDS-PAGE were transferred to nitrocellulose membranes (Micron Separations Inc., Westborough, MA, USA) with a semi-dry blotter (BioRad) and $48 \mathrm{~mm}$ Tris- $\mathrm{HCl}, 39 \mathrm{~mm}$ glycine ( $\mathrm{pH} 9 \cdot 2)$ containing methanol $20 \% \mathrm{w} / \mathrm{v}$. Filters were blocked with skimmed milk $3 \% \mathrm{w} / \mathrm{v}$ in $10 \mathrm{~mm}$ Tris- $\mathrm{HCl}, \mathrm{NaCl}$ $0.9 \% \mathrm{w} / \mathrm{v}, \mathrm{pH} 7.4$ (TBS). The filters were probed with rabbit anti-protein A serum (Medlabs, Dublin) diluted 1 in 500 in TBS containing skimmed milk $3 \% \mathrm{w} / \mathrm{v}$ and peroxidase-conjugated goat anti-rabbit IgG serum (Sigma) diluted 1 in 250 in TBS containing skimmed milk $3 \% \mathrm{w} / \mathrm{v}$. The substrate used to develop the bound peroxidase was 4-chloro-1-naphthol $0.005 \%$ and $\mathrm{H}_{2} \mathrm{O}_{2} 0.015 \% \mathrm{w} / \mathrm{v}$ in TBS.

\section{Preparation of DNA and Southern blotting}

Genomic DNA was prepared by the procedure of Lindberg et al. ${ }^{37}$ and Pattee and Neveln, ${ }^{38}$ but modified by use of recombinant lysostaphin $(60 \mu \mathrm{g})$, by performing the phenol extraction steps at ambient temperature for $45 \mathrm{~min}$ on an orbital shaker and by clarifying the phenol extracts by centrifugation at $12000 \mathrm{~g}$ in siliconised glass Corex tubes.

Standard procedures were employed for DNA manipulations. ${ }^{39}$ For Southern hybridisation, $5 \mu \mathrm{g}$ of genomic DNA was cleaved with EcoRI or HindIII and the fragments were separated by electrophoresis in an agarose $0.8 \%$ gel. The DNA was transferred to Nytran filters (Micron Separations Inc.) and probed with plasmid pSPA721 or pBBB62 DNA that had been labelled by nick translation ${ }^{40}$ with $\alpha-{ }^{32} \mathrm{P}$ dATP (Amersham). The specific activity of the dATP was $3000 \mathrm{Ci} / \mathrm{mMol}$. Plasmid pSPA721 carries the wildtype spa gene of $S$. aureus $8325-4$ on a $4 \cdot 3-\mathrm{kb}$ EcoRI 
Table I. Characteristics of $S$. aureus strains used

\begin{tabular}{|c|c|c|}
\hline Strain & Relevant characteristics & Reference no. \\
\hline $\begin{array}{l}\text { GH13, GH25, GH28, } \\
\text { GH31 }\end{array}$ & EMRSA-1 & 26 \\
\hline GH19, GH34 & MRSA & 26 \\
\hline $\begin{array}{l}\text { GH1301, GH2501, } \\
\text { GH2801 }\end{array}$ & $\mathrm{Mc}^{\mathrm{s}} \mathrm{Cd}^{\mathrm{s}} \mathrm{Hg}^{\mathrm{s}}(\mathrm{Tc})$ & 26 \\
\hline GH3101 & $\mathrm{Mc}^{\mathrm{s}} \mathrm{Cd}^{\mathrm{S}}(\mathrm{Tc})$ & 26 \\
\hline GH1901, GH3401 & $\mathrm{Mc}^{\mathrm{s}}$ & 26 \\
\hline $8325-4$ & $\begin{array}{l}\mathrm{Agr}^{+} \mathrm{Spa}^{+} \text {NCTC } 8325 \\
\text { cured of prophage }\end{array}$ & 31 \\
\hline DU5723 & $\begin{array}{l}\mathrm{Agr}^{+} \mathrm{Spa}^{-} \text {derived from } \\
\text { 8325-4 }\end{array}$ & 32 \\
\hline DU5818 & $\begin{array}{l}\mathrm{Agr}^{-} \mathrm{Spa}^{-} \text {derived from } \\
\text { DU } 5723\end{array}$ & 32 \\
\hline DU5820 & $\begin{array}{l}\mathrm{Agr}^{-} \mathrm{Spa}^{+} \text {derived from } \\
\text { (325-4 }\end{array}$ & 32,33 \\
\hline Wood46 (ISP740) & $\begin{array}{l}\text { Low level or negative } \\
\text { Spa production }\end{array}$ & 34 \\
\hline Cowan I & $\mathrm{Spa}^{+}$ & 34 \\
\hline Newman & $\mathrm{Spa}^{+}$ & 29 \\
\hline
\end{tabular}

Agr, accessory gene regulator; Spa, protein $\mathrm{A} ; \mathrm{Cd}$, cadmium; $\mathrm{Hg}$, mercury; Mc, methicillin; (Tc), reduced resistance to tetracycline.

fragment. ${ }^{28}$ Plasmid pBBB62 is pTZ18R with a 4-kb HindIII insert from strain BB270 covering mecA (constructed by Drs C. Ryffel and B. Berger-Bächi, University of Zurich; personal communication).

\section{Cell monolayers}

HEp-2 and Vero cells were grown to confluence as described previously ${ }^{9}$ in 24 -well polystyrene plates. The growth medium was Eagle's Minimum Essential Medium modified with Earle's salts (EMEM; Flow) supplemented with glutamine, non-essential amino acids and fetal calf serum (FCS) $10 \% \mathrm{v} / \mathrm{v}$. Cell monolayers were washed three times with $1 \mathrm{ml}$ of Earle's balanced salts buffered with HEPES, pH 7·1, (EBS; Flow) before use.

Mesothelial cells were prepared from human omentum. ${ }^{11}$ Cells were grown in minimum essential medium (MEM) with L-valine substituted by D-valine (MEMDval) (Gibco) and supplemented with antibiotics and FCS $10 \% \mathrm{v} / \mathrm{v}$. Cells were passaged up to three times before being used, the time to confluence varying between 3 days and 1 week. Bacterial adherence was tested within 2-3 days of confluence being reached. Mesothelial cells were identified by their cobblestone appearance when stained by the "Diff Quick" method (Merz and Dade AG, Switzerland), ${ }^{11}$ by positive staining for cytokeratin with mouse monoclonal antibody (MAb) to human cytokeratin (clone LP34, Dako Ltd), ${ }^{11,41}$ and by lack of staining with mouse MAb to human von Willebrand factor (clone RF F8:R/1) purchased from the Royal Free Hospital, Hampstead, London.

Cells were stained with rabbit anti-mouse peroxidase conjugate, developed with diaminobenzidine and $\mathrm{H}_{2} \mathrm{O}_{2}$, and visualised by light microscopy. Materials were obtained from Dako Ltd. Fibronectin was detected in mesothelial cell monolayers by direct staining with peroxidase-conjugated sheep polyclonal anti-fibronectin antibody (Binding Site Ltd, Birmingham) and developed as described for cytokeratin.

\section{Adherence assay}

The method was used as described previously. ${ }^{9,11}$ Bacterial strains were grown in IST broth supplemented with $5 \mu \mathrm{Ci} / \mathrm{ml}\left[{ }^{3} \mathrm{H}\right]$ methyl thymidine (Amersham) for $18 \mathrm{~h}$ with shaking at $37^{\circ} \mathrm{C}$. The specific activity of the tritiated thymidine was 80 or $89 \mathrm{Ci} / \mathrm{mmol}$. Cells were harvested, washed in PBS $(\mathrm{pH} 7 \cdot 2)$ and resuspended to $\mathrm{OD}_{540} 0.4$ in EBS. Bacterial suspension $(0.5 \mathrm{ml})$ at $37^{\circ} \mathrm{C}$ was added to each well containing a cell monolayer previously washed three times with $\mathrm{EBS}\left(37^{\circ} \mathrm{C}\right)$. Four, or usually six, replicate wells were prepared for each bacterial culture. After incubation for $1.5 \mathrm{~h}$ at $37^{\circ} \mathrm{C}$, the suspension was aspirated and the monolayer was washed three times with EBS $(0.5 \mathrm{ml})$. The cell monolayer plus adherent bacteria was then removed by incubation with a solution of trypsin $0.05 \% \mathrm{w} / \mathrm{v}$ and EDTA $0.02 \% \mathrm{w} / \mathrm{v}$ and transferred to scintillation fluid (Optiphase, Pharmacia) for counting. Results were expressed as counts $/ \mathrm{min}(\mathrm{cpm}) /$ monolayer $\times 100 / \mathrm{cpm}$ of the original labelled bacterial suspension. Strains for comparison were tested in the same monolayer plate to reduce the variation which occurs between plates. $^{9}$

\section{Results}

Production of protein $A$ in $M c^{R}$ strains and $M c^{S}$ variants

EMRSA-1 isolates GH13, GH25, GH28 and GH31, and MRSA isolates GH19 and GH34 were tested for protein A. Washed cells were assayed for binding of radiolabelled $\left({ }^{125} \mathrm{I}\right)$ rabbit $\mathrm{IgG}$, and supernates from lysed bacterial cells were examined by Western immunoblotting. Although the upper limit of detection of protein A was not established, quantitation with the IgG-binding assay, expressed as a percentage of IgG bound, showed that isolate GH19 produced lower levels of protein $\mathrm{A}(\leqslant 21.6 \%)$ than strain Cowan I $(\geqslant 35 \cdot 1 \%)$ or the other $\mathrm{Mc}^{\mathrm{R}}$ isolates $(\geqslant 30.0 \%)$. This was consistent with the data from Western immunoblotting for strain GH19 in which five times the amount of protein was loaded for detection of protein A (fig. 1) than was used for other $\mathbf{M c}^{\mathrm{R}}$ strains.

Strain 8325-4 produces a protein A molecule of $53 \mathrm{kDa} .{ }^{42}$ This agrees well with the mol. wt of $55 \mathrm{kDa}$ estimated from fig. 1. The protein A produced by strains GH13, GH25, GH28, GH31 and GH34 was $44 \mathrm{kDa}$ whereas that expressed by strain GH19 was $49 \mathrm{kDa}$, possibly due to loss of an IgG-binding domain $^{42}$ or repeats from the wall-associated region Xr. ${ }^{43}$

Protein A was not detected in the $\mathrm{Mc}^{\mathrm{s}}$ variant strains GH3101, GH1901 (fig. 1) and GH3401 


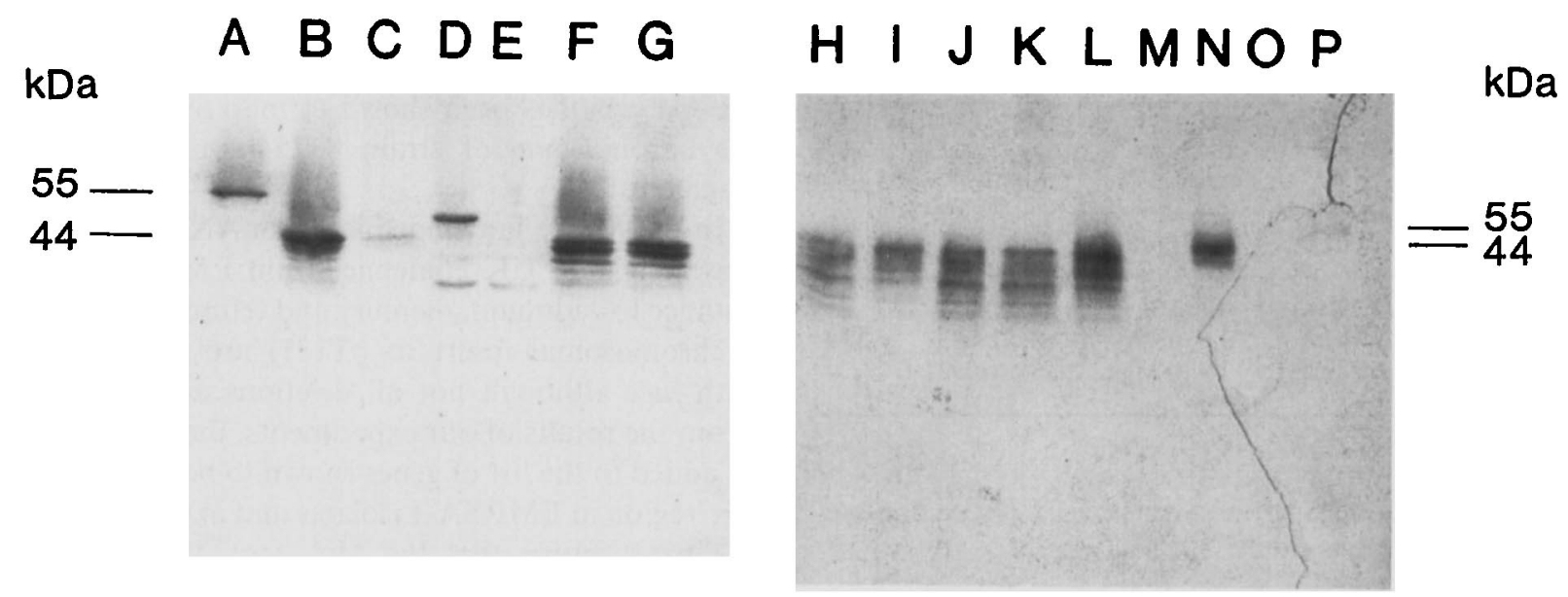

Fig. 1. Detection of protein $\mathrm{A}$ in supernates of washed lysed cells of $\mathrm{Mc}^{\mathrm{R}}$ and $\mathrm{Mc}^{\mathrm{s}}$ variant strains of $S$. aureus after SDS-PAGE and immunoblotting. Filters were probed with rabbit anti-protein A serum; $8 \mu \mathrm{g}$ of protein were loaded for all samples except $\mathrm{C}, \mathrm{D}$ and $\mathrm{E}$ which had $40 \mu \mathrm{g}$ of protein. Lanes A, P, strain 8325-4; B, GH13; C, GH1301; D, GH19; E, GH1901; F, GH25; G, GH2501; H, GH25; I, GH2501; $\mathbf{J}, \mathrm{GH} 28 ; \mathbf{K}, \mathrm{GH} 2801 ; \mathbf{L}, \mathrm{GH} 31 ; \mathbf{M}, \mathrm{GH} 3101 ; \mathbf{N}, \mathrm{GH} 34 ; \mathbf{O}, \mathrm{GH} 3401$. Protein A of strain 8325-4 is $53 \mathrm{kDa} .{ }^{42} \mathrm{The}$ numbers at the side refer to the mol. wts of the protein A from strain $8325-4(55 \mathrm{kDa})$ and strain $\mathrm{GH} 13(44 \mathrm{kDa})$.
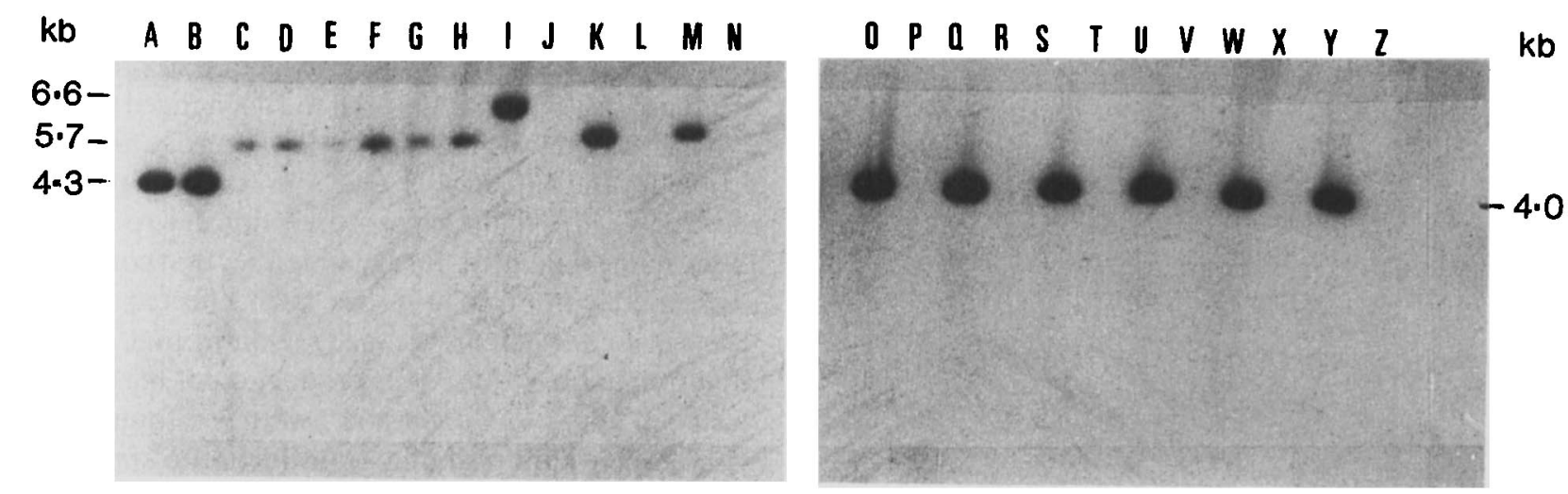

Fig. 2. Southern blot and hybridisation of genomic DNA of $S$. aureus strains. Lanes A-N, DNA digested with EcoRI and probed for spa; lanes O-Z, DNA digested with HindIII and probed for mec. Lane A, strain Newman; B, 8325-4; C, O, GH13; D, P, GH1301; E, Q, GH25; F, R, GH2501; G, S, GH28; H, T, GH2801; I, U, GH19; J, V, GH1901; K, W, GH31; L, X, GH3101; M, Y, GH34; N, Z, GH3401. Less DNA was loaded in lanes $\mathbf{C}-\mathbf{H}$.

$(\leqslant 1.3 \%$ ) by the labelled IgG-binding assay. These strains bound IgG to an extent similar to that of Wood $46(\leqslant 2.9 \%)$ which was treated as a negative control. In strain GH1301, the expression of protein A was markedly reduced in comparison to strain GH13. It was detected in Western immunoblots by increased loading of the gel (five times), but it was not detected with radiolabelled IgG. Protein A production was not reduced in strains GH2501 and GH2801 compared with their parent strains.

\section{Homology for mec and spa in $M c^{R}$ and $M c^{S}$ variant strains}

Southern blots of genomic DNA digested with $H$ indIII were probed with the 4-kb HindIII fragment of pBBB62 containing mec-specific DNA. Each MRSA strain had a $4-\mathrm{kb}$ fragment which hybridised with the mec probes (fig. 2, lanes $\mathrm{O}-\mathrm{Z}$ ). The $\mathrm{Mc}^{\mathrm{s}}$ variants GH2501, GH2801 and GH1901 lacked homology with mec, and the lack of homology previously reported for strains $\mathrm{GH} 1301, \mathrm{GH} 3101$ and $\mathrm{GH} 3401^{26}$ was confirmed (fig. 2).
For the detection of spa, genomic DNA was digested with EcoRI and Southern blots were probed with a 4.3-kb fragment from strain 8325-4 which carries the intact spa gene (fig. 2, lanes A-N). The weaker signals in lanes $\mathrm{C}-\mathrm{H}$ (fig. 2) are due to lower levels of DNA loaded as shown by ethidium bromide staining of the gel (results not shown). Each of the MRSA strains showed homology with spa. With the exception of strain GH19, which had a fragment size of $6.8 \mathrm{~kb}$, the fragment size was $5.9 \mathrm{~kb}$ (fig. 2). Lanes A and B show the $4 \cdot 3-\mathrm{kb}$ fragment of the control strain Newman and the probe strain 8325-4 respectively. Hybridisation with spa established that deletion of the spa gene in strains GH3101, GH1901 and GH3401 was associated with the phenotypic loss of protein A but that strain GH1301, which retained homology with spa on the same size fragment as the parent strain GH13, expressed reduced levels of protein A. To detect whether major alterations had occurred in the spa fragment of this variant strain, two further probes representing $5^{\prime}$ and $3^{\prime}$ terminal sequences of the spa locus of strain 8325-4 were used to hybridise with EcoRI digests of strains GH13 and GH1301. The resulting blot profile 
Table II. Adherence of $S$. aureus strains GH13 and GH1301 to cell monolayers

\begin{tabular}{l|ccc}
\hline \multirow{2}{*}{$\begin{array}{l}\text { Cell } \\
\text { monolayer }\end{array}$} & \multicolumn{2}{|c}{$\begin{array}{c}\text { Percentage adherence } \\
\text { (SD) of strain }\end{array}$} & $\begin{array}{c}\text { Mann-Whitney } \\
\text { U Test } \\
\text { p value }\end{array}$ \\
\cline { 2 - 3 } & GH13 & GH1301 & \\
\hline HEp-2 & $9 \cdot 7(0 \cdot 6)$ & $4 \cdot 1(1 \cdot 3)$ & 0.024 \\
Vero & $9 \cdot 1(1 \cdot 8)$ & $1 \cdot 0(0 \cdot 1)$ & 0.0022 \\
Mesothelial & $6 \cdot 7(0.55)$ & $1 \cdot 9(0 \cdot 23)$ & 0.0022 \\
\hline
\end{tabular}

Table III. Adherence to mesothelial cells of agr and spa mutants of $S$. aureus strain $8325-4$

\begin{tabular}{ll|rc}
\hline Strain & Phenotype & $\begin{array}{c}\text { Percentage } \\
\text { adherence } \\
(\mathrm{SD})\end{array}$ & $\begin{array}{c}\text { Mann-Whitney } \\
\text { U test* } \\
\text { p value }\end{array}$ \\
\hline $8325-4$ & $\mathrm{Agr}^{+} \mathrm{Spa}^{+}$ & $5 \cdot 43(0 \cdot 49)$ & - \\
DU5723 & $\mathrm{Agr}^{+} \mathrm{Spa}^{-}$ & $5 \cdot 13(0 \cdot 34)$ & $0 \cdot 7$ \\
DU5818 & $\mathrm{Agr}^{-} \mathrm{Spa}^{-}$ & $12 \cdot 43(0 \cdot 29)$ & $0 \cdot 03$ \\
DU5820 & $\mathrm{Agr}^{-} \mathrm{Spa}^{+}$ & $13 \cdot 6(0 \cdot 18)$ & $0 \cdot 03$ \\
\hline
\end{tabular}

${ }^{*}$ Comparison with strain 8325-4.

for strain GH1301 was unchanged compared with strain GH13 (not shown).

\section{Adherence of strains GH13 and GH1301 to cell monolayers and the role of spa and agr in adherence of strain 8325-4}

With HEp-2, Vero and mesothelial cell monolayers, strain GH13 adhered at levels which were consistently and significantly greater than those for strain GH1301, which produced low levels of protein A (table II). Similar results were obtained in repeat experiments. To test the apparent correlation between low level production of protein A and reduced adherence to cell monolayers, mutants of strain 8325-4 for spa and agr were compared with strain $8325-4$ for adherence to mesothelial cells. The spa mutation in strain DU5723 had no effect on adherence compared with strain 8325 4 (table III). Strain 8325-4 produced low levels of protein A which was considerably increased in the agr mutant (DU5820). Mutation at the agr locus in both the $s p a^{-}$strain DU5818 and in the $s p a^{+}$strain DU5820 resulted in a significant increase in the levels of adherence compared with strains 8325-4 and DU5723 (table III). Similar results were obtained in repeat experiments.

\section{Discussion}

It has been known for some time that protein $\mathrm{A}$ production in $S$. aureus is affected by gain or loss of methicillin resistance. Cohen and Sweeney ${ }^{27}$ showed that protein A production could be co-eliminated and co-transduced with methicillin resistance, suggesting that the mec and spa loci are linked. By pulse-field gel electrophoresis and transformation linkage analysis, the spa gene has been shown to map near to mec on the chromosome of strain 8325-4 in the SmaI G fragment. ${ }^{28,44}$

In the Australian epidemic strain ANS46 ${ }^{25}$ and the closely related UK epidemic strain EMRSA-1, ${ }^{26}$ resistance to cadmium, mercury and tetracycline (due to a chromosomal insert of pT181) are co-eliminated with $m e c$ although not all deletions are identical. ${ }^{45}$ From the results of our experiments, the spa gene can be added to the list of genes shown to be linked to the mec region in EMRSA-1 isolates and in other MRSA. We have shown that the $\mathrm{Mc}^{\mathrm{s}}$ derivative, GH3101, which retains mercury resistance and homology for a merA probe ${ }^{26}$ has lost homology for spa in this mecregion deletion. Similarly, the MRSA derivatives, GH1901 and GH3401 lost homology for spa along with homology for mec. In comparison, the EMRSA1 derivatives $\mathrm{GH} 2501$, GH2801 and GH1301, which have lost resistance to $\mathrm{Cd}, \mathrm{Hg}$ and $\mathrm{Tc}$, retained homology for spa. The marked reduction of protein A produced by strain GH1301 but the unchanged pattern of hybridisation with the 4.3-kb EcoRI probe and with probes for the sequences $3^{\prime}$ and $5^{\prime}$ to $s p a$, indicates that the change in level of expression is not due to a gross DNA re-arrangement. It suggests either that control of expression of protein $A$ has been effected by the deletion somewhere in the $m e c$ region or that a point mutation in spa required for production of the protein has been affected. Cohen and Sweeney ${ }^{27}$ found that, with certain donor strains, transduction of mec into strain 8325 would increase or reduce the level of protein A produced, suggesting that the mec region can affect expression of protein A. The agr locus, which represses protein A production in the post-exponential growth phase, maps at a site distant from mec and $s p a^{44}$ so it is unlikely that the observed changes in level of expression of protein A involve this locus directly. Cohen and Sweeney ${ }^{27}$ found that mutations to highlevel protein A production in strain 8325, which are presumably in agr, were unaffected by introduction of mec.

The MRSA strains have larger spa fragments than strain $8325-4(4.3 \mathrm{~kb})$. The differences in fragment size between strain GH19 $(6.7 \mathrm{~kb})$ and the EMRSA-1 and GH34 strains $(5.9 \mathrm{~kb})$ suggest that strain GH19 is less closely related. Strains GH19 and GH34 are distinct from each other and from the EMRSA-1 isolates used in this study, both in phage type and in the range and location of antimicrobial resistances. ${ }^{26}$ The smaller size of protein $\mathrm{A}$ in the clinical isolates compared to strain 8325-4 could be because their spa gene lacks one of the five major repeats present in that of strain $8325-4 .{ }^{42}$

The mec deletion in strain GH1301, which showed reduced production of protein $A$ and reduced adherence, indicated that protein A might be involved in adherence, as has been suggested in other studies. ${ }^{10}$ From experiments with agr and spa mutations of strain 
8325-4 our results show that protein A does not significantly affect adherence to mesothelial cells although there is a significant increase in adherence in $a g r^{-}$mutants compared with $a g r^{+}$strains. This suggests that a cellular product in exponential growth is involved. The advantage of using site-specific mutations avoids the problems of other mutations which might be present after chemical mutagenesis or spontaneous mutation. ${ }^{46}$ If the results with strain 8325-4 are applicable to the MRSA strains, a factor other than reduced production of protein $\mathrm{A}$ in strain GH1301 is needed to explain the reduction in adherence and suggests that a structural gene involved in adherence or a gene that regulates its expression resides in the mec region. Retention of spa gene homology may not affect this interpretation, as similar results for adherence to HEp-2 and mesothelial cells were obtained with strain GH31 and strain GH3101, which is $s p a^{-}$(unpublished observations).

Fibronectin has been detected on the surface of human mesothelial cells in some ${ }^{11,47}$ but not in other studies. ${ }^{48}$ Growth conditions affect the amount of

\section{References}

1. Noble WC, White MI. Staphylococcal skin infections in man. In: Easmon CSF, Adlam C (eds) Staphylococci and staphylococcal infections. London, Academic Press. 1983: 165-191.

2. Dancer SJ, Noble WC. Nasal, axillary and perineal carriage of Staphylococcus aureus among women: identification of strains producing epidermolytic toxin. J Clin Pathol 1991; 44: 681-684.

3. Dyas AC, Eden PJ, Eastwood D et al. Sources of staphylococcal wound sepsis. J Hosp Infect 1982; 3: 345-350.

4. Sewell CM, Clarridge J, Lacke C, Weinman EJ, Young EJ. Staphylococcal nasal carriage and subsequent infection in peritoneal dialysis patients. J Am Med Assoc 1982; 248: 1493-1495.

5. Davies SJ, Ogg CS, Cameron JS, Poston SM, Noble WC. Staphylococcus aureus nasal carriage, exit site infection and catheter loss in patients treated with continuous ambulatory peritoneal dialysis (CAPD). Peritonal Dialysis International $1989 ; 9: 61-64$.

6. Pignateri A, Pfaller M, Hollis R, Sesso R, Leme I, Herwaldt L. Staphylococcus aureus colonisation and infection in patients on continuous ambulatory peritonal dialysis. $J$ Clin Microbiol 1990; 28 : 1898-1902.

7. Beachey EH. Bacterial adherence: adhesion-receptor interactions mediating the attachment of bacteria to mucosal surfaces. J Infect Dis 1981; 143: 325-345.

8. Jordens JZ. Adherence of Staphylococcus aureus to HEp2 monolayers and fibronectin. In: Wadstrom T, Eliasson I, Holder I, Ljungh A (eds) Pathogenesis of wound and biomaterial-associated infection. Springer-Verlag London. 1990: 325-327.

9. Wyatt JE, Poston SM, Noble WC. Adherence of Staphylococcus aureus to cell monolayers. J Appl Bacteriol 1990; 69: 834-844.

10. Haagen IA, Heezius HC, Verkooyen RP, Verhoef J, Verbrugh HA. Adherence of peritonitis-causing staphylococci to human peritoneal mesothelial cell monolayers. $J$ Infect Dis $1990 ; 161: 266-273$.

11. Glancey GR, Cameron JS, Ogg CS, Poston S. Adherence of Staphylococcus aureus to cultures of human peritoneal mesothelial cells. Nephrol Dial Transplant 1993; 8: $157-162$.

12. Kuusela P. Fibronectin binds to Staphylococcus aureus. Nature 1978; 276: 718-720.

13. Flock J-I, Froman G, Jonsson $\mathrm{K}$ et al. Cloning and expression fibronectin produced by cells. ${ }^{47}$ Mesothelial cells grown in MEM-Dval, as in this study, produce some surface fibronectin which is increased when cells are grown in standard media with L-valine. ${ }^{11}$ However, as transformed cells may not contain fibronectin, ${ }^{16}$ unlike primary cell cultures, the similar results for adherence of strains GH13 and GH1301 to HEp-2, Vero and mesothelial cells in this study suggest that a binding site(s) other than, or in addition to, fibronectin is involved. ${ }^{10}$ It has been shown ${ }^{49}$ that anti-fibronectin antibody reduced adherence of $S$. aureus to fibronectin to a greater extent than to mesothelial cells, suggesting an additional receptor site on mesothelial cells. The increase in adherence in agr mutants independent of spa suggests that agr, which controls expression of a wide range of cell-bound components and extracellular products, controls expression of a locus involved in adhesion. The correlation between levels of protein A produced and levels of adherence to cells ${ }^{\mathbf{1 0}}$ could also be explained if another surface component, which is similarly under agr control, was responsible for adherence. of the gene for a fibronectin-binding protein from Staphylococcus aureus. EMBO J 1987; 6: 2351-2357.

14. Lindberg M, Jonsson K, Muller H-P et al. Fibronectin binding proteins in Staphylococcus aureus. In: Novick RP (ed) Molecular biology of the staphylococci. New York, VCH Publishers Inc. 1990; 343-356.

15. Hynes RO. Alteration of cell-surface proteins by viral transformation and by proteolysis. Proc Natl Acad Sci USA 1973; 70: $3170-3174$.

16. Ruoslahti E, Vaheri A. Novel human serum protein from fibroblast plasma membrane. Nature 1974; 248: 789-791.

17. Proctor RA. Fibronectin: a brief overview of its structure, function and physiology. Rev Infect Dis 1987; 9 Suppl 4: S317-S321.

18. Boden MK, Flock J-I. Fibrinogen-binding protein/clumping factor from Staphylococcus aureus. Infect Immun 1989; 57 : 2358-2363.

19. McDevitt D, Vaudaux P, Foster TJ. Genetic evidence that bound coagulase of Staphylococcus aureus is not clumping factor. Infect Immun 1992; 60: 1514-1523.

20. Recsei P, Kreiswirth B, O'Reilly M, Schlievert P, Gruss A, Novick RP. Regulation of exoprotein gene expression in Staphylococcus aureus by agr. Mol Gen Genet 1986; 202: 58-61.

21. Peng H-L, Novick RP, Kreiswirth B, Kornblum J, Schlievert P. Cloning, characterisation and sequencing of an accessory gene regulator (agr) in Staphylococcus aureus. J Bacteriol $1988 ; 170: 4365-4372$.

22. Kornblum J, Kreiswirth BN, Projan SJ, Ross H, Novick RP. Agr: a polycistronic locus regulating exoprotein synthesis in Staphylococcus aureus. In: Novick RP (ed) Molecular biology of the staphylococci. New York, VCH Publishers Inc. 1990: 373-402.

23. Beck WD, Berger-Bächi B, Kayser FH. Additional DNA in methicillin-resistant Staphylococcus aureus and molecular cloning of mec-specific DNA. J Bacteriol 1986; 165: 373-378.

24. Skinner S, Inglis B, Matthews PR, Stewart PR. Mercury and tetracycline resistance genes and flanking repeats associated with methicillin resistance on the chromosome of Staphylococcus aureus. Mol Microbiol 1988; 2: 289-292.

25. Matthews $P R$, Inglis $B$, Stewart PR. Clustering of resistance genes in the mec region of the chromosome of Staphylococcus aureus. In: Novick RP (ed) Molecular biology of the staphylococci. New York, VCH Publishers Inc. 1990: 69-83.

26. Poston SM, Li Saw Hee F-L. Genetic characterisation of resistance to metal ions in methicillin-resistant Staphy- 
lococcus aureus: elimination of resistance to cadmium, mercury and tetracycline with loss of methicillin resistance. $J$ Med Microbiol 1991; 34: 193-201.

27. Cohen S, Sweeney HM. Modulation of protein A formation in Staphylococcus aureus by genetic determinant for methicillin resistance. J Bacteriol 1979; 140: 1028-1035.

28. Patel AH, Foster TJ, Pattee PA. Physical and genetic mapping of the protein A gene on the chromosome of Staphylococcus aureus 8325-4. J Gen Microbiol 1989; 135: 1799-1807.

29. Duthie ES, Lorenz LL. Staphylococcal coagulase: mode of action and antigenicity. $J$ Gen Microbiol 1952; 6: 95-107.

30. Marples RR, Cooke EM. Current problems with methicillinresistant Staphylococcus aureus. J Hosp Infect 1988; 111: 381-392.

31. Novick RP. Properties of a high frequency transducing phage in Staphylococcus aureus. Virology 1963; 33: 155-166.

32. Patel AH, Nowlan P, Weavers ED, Foster T. Virulence of protein A-deficient and alpha-toxin-deficient mutants of Staphylococcus aureus isolated by allele replacement. Infect Immun 1987; 55: 3103-3110.

33. O'Reilly M, de Azavedo JCS, Kennedy S, Foster TJ. Inactivation of the alpha-haemolysin of Staphylococcus aureus $8325-4$ by site directed mutagenesis and studies on expression of its haemolysins. Microb Pathog 1986; 1: $125-138$

34. Uhlen M, Guss B, Nilsson B, Gotz F, Lindberg M. Expression of the gene encoding protein A in Staphylococcus aureus and coagulase-negative staphylococci. $J$ Bacteriol 1984; 159: 713-719.

35. Lowry OH, Rosebrough NJ, Farr AL, Randall RJ. Protein measurement with the Folin phenol reagent. $J$ Biol Chem $1951 ; 193: 265-275$

36. Laemmli UK. Cleavage of structural proteins during the assembly of the head of bacteriophage T4. Nature 1970; 227: $680-685$

37. Lindberg M, Sjostrom JI, Johansson T. Transformation of chromosomal and plasmid characters in Staphylococcus aureus. $J$ Bacteriol 1972; 109: 844-847.

38. Pattee PA, Neveln DS. Transformation analysis of three linkage groups in Staphylococcus aureus. J Bacteriol 1975; 124: 201-211.

39. Ausubel FM, Brent R, Kingston RE et al. Current protocols in molecular biology. New York, John Wiley and Sons Inc. 1987.

40. Rigby PWJ, Diekman M, Rhodes C, Berg P. Labelling deoxyribonucleic acid to high specific activity in vitro by nick translation with DNA polymerase. J Mol Biol 1977 ; 113: $237-251$.

41. Stylianou E, Jenner LA, Davies M, Coles GA, Williams JD. Isolation, culture and characterisation of human peritoneal mesothelial cells. Kidney Int 1990; 37: 1563-1570.

42. Finck-Barbancon V, Prevost G, Mazurier I, Piemont Y. A structurally novel staphylococcal protein A from the V8 strain. FEMS Microbiol Lett 1992; 91: 1-8.

43. Shuttleworth HL, Duggleby CJ, Jones SA, Atkinson T, Minton NP. Nucleotide sequence analysis of the gene for protein A from Staphylococcus aureus Cowan I (NCTC 8530) and its enhanced expression in Escherichia coli. Gene 1987; 58: 283-295.

44. Pattee PA, Lee H-C, Bannantine JP. Genetic and physical mapping of the chromosome of Staphylococcus aureus. In: Novick RP (ed) Molecular biology of the staphylococci. New York, VCH Publishers Inc. 1990: 41-58.

45. Inglis B, Matthews PR, Stewart PR. Induced deletions within a cluster of resistance genes in the mec region of the chromosome of Staphylococcus aureus. $J$ Gen Microbiol $1990 ; 136$ : 2231-2239.

46. Foster TJ, O'Reilly M, Phonimdaeng P, Cooney J, Patel AH, Bramley AJ. In: Novick RP (ed) Molecular biology of the staphylococci. New York, VCH Publishers Inc. 1990: 403-417.

47. Rheinwald JG, Jorgensen JL, Hahn WC, Terpestra AJ O'Connell TM, Plummer KK. Mesosecrin: a secreted glycoprotein produced in abundance by human mesothelial, endothelial and kidney epithelial cells in culture. $J$ Cell Biol 1987; 104: 263-275.

48. Verbrugh HA. Adherence of staphylococci to monolayers of human mesothelial cells and their removal by phagocytes. In: Wadstrom T, Eliasson I, Holder I, Lungh A (eds) Pathogenesis of wound and biomaterial-associated infections. Springer-Verlag. 1990: 361-365.

49. Glancey GR, Suassuna J, Wyatt JE, Poston S, Ogg CS, Cameron JS. Interleukin-1 (IL-1) increases the adherence of $S$. aureus to peritoneal mesothelial cells. Peritoneal Dialysis International XI Annual CAPD Abstracts 1991 (no. 96). 